\title{
EFFECTS OF COMBINATION BETWEEN RELAX MASSAGE AND DR BACH FLOWER REMEDIES ON EVERYDAY STRESS
}

\author{
Mariana Angelcheva, Simona Petkova \\ National Sports Academy „Vassil Levski”, Sofia, Bulgaria
}

\begin{abstract}
There are few research studies of the effect on human's physical relaxation methods coupled with emotional relaxation methods. Having in mind the goals of our experiment, we applied a combined impact technology of the anti-stress massage and individualized Dr Bach Flower Essences' combination. The type of personalized combination needed is set by a licensed Bach therapeutic doctor. Fifty-seven persons (43 females and 14 males), aged between 20 and 50, have been included in the study. After the end of the procedure course, using standardized sociological questionnaire, we studied the preferences of everyone client and his/her argumentation in order to select the concrete anti-stress procedure in the SPA-center. The results show that all persons under observation are satisfied with the applied procedures and consider the combination of anti-stress massage and Dr Bach's elixirs has a relaxing effect on their physical and emotional systems. 65 per cent have decided to prefer them to go on again procedures. This has convinced us to perceive the notion that a combined impact of relax massage and Dr Bach's anti-stress elixir may guarantee deeper psychophysical relaxation. This occurs a sure card for the method to be more extensively applied in various SPA complexes.
\end{abstract}

Key words: classic relax massage, shiatsu massage, stress, distress

\section{INTRODUCTION}

In the last three decades the social environment has been changed many times more than in the last three centuries. In its International Action Plan for psychic health, 2020, the World Health Organization defines stress and distress as 'the disorders of the $21^{\text {st }} \mathrm{c}$." Its ambition is to reduce the factors causing them by 10 per cent till the end of the decade.

An EU study, using the Copenhagen Psychological Questionnaire, ascertains that each fifth Bulgarian is living under stress. There is a sudden jump-up of the psycho disorders in this society. Bulgarians occur to be among the most nervous EU citizens. Recent data, publicly announced by the Bulgarian National Statistic Institute on September 8, 2019, are similar: 8 per cent of the population of the country indicates the stress in the office as a serious factor influencing their health status; the process goes deeper and intensifies its dynamics; expectancy is that this percentage will sharply go up. According to the International Labor Institute, because of stress, world economy is losing $\$ 200$ billion per year. It is a result not only of the decreased work capacity and worsened labor quality but also because of the hospital and ambulance medical treatment, sick-leaves and various other social and economic factors.
Hans Celier, a Canadian endocrinologist, is the first to define the stress as a "non-specific (physiologic) answer of organism to any requirement that challenges it" (Celier, 1982). Total lack of stress means death, i.e. 'stress means life' (Atanassov, 2002). According to Celier, each social change is a stress source and it sets in motion the inner for the individual organism adaptive mechanism.

Whether the stress will convert into a distress or not depends only on us, on our emotional and behavioral attitudes, and on the reactivity capacity of our own body. As a perception of distress, we understand all hard-worldly situations which the Self of each single individual cannot overcome alone. Lazarus (Lazarus,1994) perceives stress as a relationship between individual persona and common environment; it is the person, in this relation, who assesses the environment. In other words, physiological and psychological stresses give birth to identical, similar physiological answers. However, while in case of physiological stress they are always stereotyped (non-specific), the psycho-stress not always leads to the expected reactions. They are quite diverse: threat, anger, depression, anxiety, activity disturbs, etc. (Lazarus, 1966). Positive stress reading defines it as a balance between the environmental requirements and the individual human 
abilities to respond to these requirements (Savova, 2012). The events, accepted by people as stress ones, are called stressors. They are various but all, in principle, provoke one and the same biological stress reaction (Celier, 1982).

According to Simeons (Simeons, A. 1961), while the Self-assessment is endangered, human brain programs each individual either to struggle or to run away. In his classic work Man's Presumptions Brain: An Evolutionary Interpretation of Psychosomatic Disease, Simeons (Ibid., 1961), describes psychosomatic disorder evolution. According to him, human brain, in particular big hemispheres, cannot develop so, to such a degree, that to obtain the capacity needed to cope with the $20^{\text {th }} \mathrm{c}$. stress pressure in a relevant rhythm. Stress products destroy human organism; the result is coming into sight of psycho-somatic disorders.

Endocrinologists proved stress positions itself as original mediator between social environment and natural genetic human apparatus. Stress hormones influence, spontaneously and directly, the individual genes (Solomon, Mikulincer, Flum, 1988).

It is well known fact, physical exercises are some of the active methods to fight everyday stress and transformation of the stress hormones into hormones of 'muscles delight' (Gencheva, 2008).

Massage, classical or reflex, is one of the most ancient methods to get passive nerve-psychic relaxation. It is well-known fact, massage correct execution may lead to an enjoyable sensation accomplished by blood vessel extension, local temperature increase, tissue warming and tissue tension decrease, pain easing, muscle tonus reduction, Self-confidence and cheerfulness increase, etc.

There are many research studies on how to overcome the stress. (Domuschieva-Rogleva, 2009: Domuschieva-Rogleva, Iancheva \& Shopov,2017: Domuschieva-Rogleva, Iancheva, 2017)

Dr Bach formulates his strategy to cope with the everyday stress as follows: „Do not struggle with it, just transform it". Even today his method is actively practiced, and it happens so due to the efforts of licensed therapists who have the right to set specific individual combination of Bach flower essences individually for everyone. Such a combination acts as an adaptogen in the fight against everyday stress. The essences may be received internally or as a component of a massage cream in order to be absorbed through the skin and so to realize their effect via nerve-reflex system.

Some of anti-stress studies are related to the $\mathrm{Dr}$ Bach Flower Essences. Below we mention some of them (www.researchgate.net or www.biomedcentral.com)

Walach et al, 2001, studied 61 healthy university students preparing their exams; they were divided into two groups - test and control; the former is receiving Bach Flower Remedy and the latter - placebo. There were no significant differences in the outcomes of both groups at the end of the day; final results of all participants proved in both of them proved a significant fall of the observed pre-test anxiety (www.sciencedirect.com).

Pintov et al, 2005, assess the effect of the Bach Flower remedy in a group of 40 children, aged between 7 and 11, who suffer attention/hyperactivity deficit (ADHD). They have been divided into two groups: members of the one receiving flower essences and of the second - placebo. A significant difference in their final outcomes was not registered; however, there were visible improvements registered. (doi. org/10.1016/j.ejpn.2005.08.001).

Balgobin et al, 2015, supported by Bach Center and Twelve Healers, conducted a pilot study in Britain, led by The British Flower \& Vibrational Essences Association; it examined the impact, if any, essence therapy has on emergency (police, fire brigade, ambulance, paramedics) and health service workers, suffering from stress. $73 \%$ of participants have completed the study and showed good reduction in their stress levels, they have been treated by the 34-question CORE-OM instrument. In advance, the participants have had been randomly allocated to one of the following two groups: (a) individualized Bach Remedy therapy; and (b) Bach Rescue Remedy ${ }^{\oplus}$ only. The latter has acted as a control group. Severe challenges in recruiting participants have been encountered and the resulting sample size has occurred far smaller than intended. Notwithstanding this, the results indicate Bach Flower Essences could play a useful role in supporting emergency and health workers in work-related stress management. The outcome exponents show 
good results, the stress levels decrease substantially. The research study proves that both methods - individualized treatment under Bach method and the Rescue Remedy $\odot$ application alone, may have positive effect. However, the results show as well that individualized treatment is better than the standardized Rescue Remedy $\odot$, which is expectedly, having in mind the philosophy of flower essence treatment. (www.bachcentre.com).

Nonetheless, various combined methods for stress bridging are relatively weakly studied. In fact, this occurred to be our basic argument to conduct such a research as in respect to the combined effect of the anti-stress massage and the Bach flower essences.

The aim. To study the combined impact of anti-stress massage and Dr Bach flower essences on the psycho-physic state of the persons included in the respondent group and their preferences for anti-stress procedures, offered by the SPA-center.

\section{METHOD}

Fifty-seven persons (43 females and 14 males), aged 20-50 took part in our research study. The observation time was of three months in a SPA-center. A licensed Bach therapist held the individual interviews after participant's informed agreement; the goal was to set individualized combination of Bach essences that can recuperate client's emotion$\mathrm{al}$ and physical balance. Before the procedure to start, the client had to receive 4 drops of Bach anti-stress elixir, dissolved in $100 \mathrm{ml}$ spring water; an additional essence had to be supplemented; it was set by the licensed Bach therapist due to the data obtained through the individual questionnaire. Then, there is a 50-minute relax holistic massage; we enriched it with some elements of shiatsu technique; it was held in a preliminary warmed room where we created an environment of muted light and gentle music against the background of spread aroma of anti-stress Bach perfume. For the goals of our study, the massage was processed by rubbing in the skin a mixture of massage oil and anti-stress Bach elixir (The Flower Massage ${ }^{\circledR}$ ). Each client has got between 5 and 7 massages. The procedures have been held once per two days. After the end of procedure course, we have used a standard sociological questionnaire to register each client preferences to select this anti-stress relax program.

\section{RESULTS}

Final data obtained from the questionnaire registered the following perception:

In accordance to criterion sex - 75 per cent females, and 25 per cent males.

In accordance to criterion age - the most numerous group is the one of people aged between 40 and 50; i.e. persons in their mature labor active life-stage coming from both sex groups; the second multifold group was of the youngest respondents - age 20-30; interesting fact we registered in the third numerous group: there were some age division - the males in the group were above 50 , and the females - between 30 and 40.

In accordance to the criterion attendance - the highest population was in the group using the service only during the vacancies; in this sense both genders have one and the same judgment; most scanty was the group of people who used the service every month.

In accordance to the criterion preference -from the data obtained, it becomes obviously that 11 persons of the respondent totality beloved mostly this procedure, and 16 were visiting the SPA-center just to satisfy their personal curiosity and to test some novelty.

In accordance to the criterion satisfaction - independently from the motives for coming to the SPA-center all respondents, questioned, were pleased with their individual decision; there was no even a single negative answer. At the end of the day for all and one the pre-procedure tension had fallen, psychically and emotionally.

In accordance to the criterion willingness for future choice - the whole respondent group, as totality, answered in a positive tone for its will to choose anti-stress procedure with flower essences again in future - 65 per cent did make categorical decision ("Yes, definitely") and 35 per cent were hesitating a 
little bit („I think Yes”) (Figure 1).

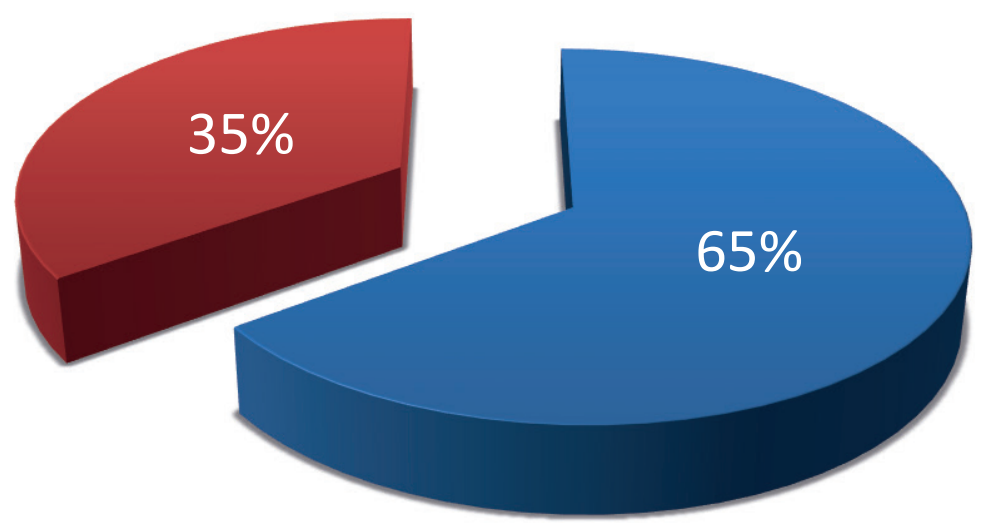

Figure 1. Respondents' ratio on whether to choose again the procedure or not

\section{DISCUSSION}

In the last decades an increased interest toward the methods of complementary and alternative medicine have been observed. Some of the reasons are: a) up-going prices of health services; b) their quality; and c) the demand for additional effective and non-expensive therapies improving health and prosperity. In our opinion, one of the most popular and attracting interest methods which has been the closest to our study, occurred to be related to aromatherapy and aroma-therapeutic massage. Due to the literature review of various studies in the respective field (Popova-Dobreva, Gencheva, 2012), perhaps, the closest to the conceptual design of our study, again in our view, is Cooke M et al., 2007 (cited after Popova-Dobreva, Gencheva, 2012). Its research team goal has been to assess the impact of aromatherapy massage coupled with music, on stress and anxiety levels measured in the group of nurses working for emergency service. The results have demonstrated that the applied combined procedure decreases significantly anxiety. So, the authors recommend this procedure to be applied at the very work place, in the very office, in order to escape the unpleasant sequences as in respect to physical and psychical workers' health, the nurses in the respective case study.

\section{CONCLUSION}

Data, obtained during our research, show an increase of male attention to the relax procedures in the SPA-center. To prevent their health becomes an important social aim for males as well, not only for women. It makes impression that anti-stress re- laxes massages coupled with Dr Bach elixir attract people, both sexes, in their active laborious age. The group aged 40-50 occurred to be the most numerous one. Perhaps, it is so, because of the higher stress levels and their better, improved financial opportunities. Due to the change dynamics of lifestyle and life quality, the group, interesting in these services, that follows next, is the one of the youngest participants, aged 20-30. The fact that all tested persons wish to repeat the procedure is real; it gives us the argument that the combined impact of relax massage and anti-stress Bach elixir guarantees deeper psycho-physical relaxation. This makes the method appropriate for a broader implementation in various SPA-complexes.

\section{REFERENCES}

Atanassov, N. (2002). Teorii za psihichnoto razvitie v prihoanalizata, Acad. Izd. "Prof. M. Drinov", Sofia

Domuschieva-Rogleva, G. (2009). Predsastezatelna trevojnost i stress vav sporta, Izd. "Ivoform", Sofia

Domuschieva-Rogleva, G., Iancheva, T. \& Shopov, A. (2017). Dinamics of anxiety and perceived stress by the participants in the XXV Antarctic expedition. In: Journal of Applied Sports Sciences Vol. 2, pp.31-41

Domuschieva-Rogleva, G, Iancheva, T. (2017). Coping strategies for the participants in the Antarctic expedition. In: Revista de Psicología del Deporte., Vol 26, Suppl 4, pp. 45-50 Journal of Sport Psychology, Vol 26, Suppl 4, pp. $45-50$

Gencheva, N. (2008). Nashiat opit pri lechenie na bolki v garba s Fit-ball gimnastika; Sbornik nauchni trudove na Rusenski universitet; tom 47, seria 5.4, pp. 93-97, Rouse 
Popova-Dobreva, D., Gencheva, N. (2012). Literaturen pregled na publikacii, svarzan s Wellness \& Aromatherapy; spisanie "Sport i nauka", izvanreden broi 1, pp. 135 141, Sofia

Savova, Z. (2012). Prevencia na stress I profesionalno izcherpvane, Izd. "Simolini 94", Sofia

Celier, H. (1982). Stress Without Distress, Bulgarian translation by Izd. "Nauka i izkustvo", Sofia

Balgobin, S. (2015). The Impact of the Bach Flower Remedies on Stress Among Emergency and Health Service Workers, A Pilot Study, British Flower \& Vibrational Essences Association, June 2015 https://www.bachcentre. com/centre/research_2015_08.pdf

Lazarus, R.S. (1966). Psychological stress and the coping process. New York: McGraw Hill.

Lazarus, R. (1994). Emotion and adaptation, Oxford University Press, Oxford

Pintov, S. (2005). Bach flower remedies used for attention deficit hyperactivity disorder in children-A prospective double-blind controlled study, European Journal of Paediatric Neurology, November 2005, Vol. 9, Issue 6, pp. 395-398

Solomon, Z., Mikulincer, M., Flum, H. (1988). Negative life events, coping responses, and combat-related psychopathology, Journal of Abnormal Psychology

Simeons, A. (1961). Man's Presumptious Brain: An Evolutionary Interpretation of Psychosomatic Disease

Walach, H. (2001). Efficacy of Bach-flower remedies in test anxiety: A double-blind, placebo-controlled, randomized trial with partial crossover, Journal of Anxiety Disorders, Volume 15, Issue 4, July-August 2001, pp. 359-366

https://www.researchgate.net/publication/26241616 (accessed Sep 03 2019)

http://www.biomedcentral.com/1472-6882/9/

https://doi.org/10.1016/j.ejpn.2005.08.001

https://www.sciencedirect.com/science/article/pii/ S088761850100069X

Corresponding author Mariana Angelcheva, MD, Kinesitherapy and Rehabilitation Department National Sports Academy "V. Levski", 1, Gurguljat Str., 1117 Sofia, Bulgaria; angelcheva_dr@abv.bg 